Portland State University

PDXScholar

Spring 1989

\title{
Perspectives on Urban Economic Planning: The Case of Washington, D.C., Since 1880
}

Carl Abbott

Portland State University, d3ca@pdx.edu

Follow this and additional works at: https://pdxscholar.library.pdx.edu/usp_fac

Part of the Urban Studies and Planning Commons

Let us know how access to this document benefits you.

Citation Details

Abbott, C., Perspectives on Urban Economic Planning: The Case of Washington, D.C., Since 1880. The Public Historian, Vol. 11, No. 2 (Spring, 1989), pp. 5-21.

This Article is brought to you for free and open access. It has been accepted for inclusion in Urban Studies and Planning Faculty Publications and Presentations by an authorized administrator of PDXScholar. Please contact us if we can make this document more accessible: pdxscholar@pdx.edu. 


\title{
Research
}

\section{Perspectives on Urban Economic Planning: The Case of Washington, D.C., Since 1880}

\author{
Carl Abbott
}

There IS LitTLE DOUBT that the United States has been undergoing a sweeping and multi-faceted economic transformation since the early 1970s. The industrial mix and spatial distribution of activities within the national economy are being altered by basic changes, including (1) the simultaneous growth of certain manufacturing industries and the decline of others, (2) the broad decentralization of manufacturing production to overseas locations and the rising importance of international trade, (3) the shift of employment from manufacturing and transportation into information processing activities, and (4) the emergence of historically peripheral regions in the South and West as centers of innovation and economic change. ${ }^{1}$

In varying combinations, these changes are altering the economic circumstances of American cities and forcing reconsideration of appropriate economic roles. With the effective withdrawal of the federal government

Research for this essay was made possible by the support of the Center for Washington Area Studies, the George Washington University.

1. For examples of ways to conceptualize the changes, see Barry Bluestone and Bennett Harrison, The Deindustrialization of America (New York: Basic Books, 1982); Larry Sawers and William Tabb, eds., Sunbelt/Snowbelt: Urban Development and Regional Restructuring (New York: Oxford University Press, 1984); Alfred Watkins and David Perry, eds., The Rise of the Sunbelt Cities (Beverly Hills: Sage Publications, 1977); Daniel Bell, The Coming of Post-Industrial Society (New York: Basic Books, 1973); George Sternlieb and James Hughes, eds., Post-Industrial America (New Brunswick, N.J.: Center for Urban Policy Research, 1975). 
as an initiator of local economic development in the 1980s, responsibility has fallen on states and municipalities as the traditional promoters of urban growth. ${ }^{2}$ State economic development agencies, blue-ribbon panels, futures task forces, and special economic planning committees in a variety of versions have all aimed to consider what their various cities should do next. In some cases, the result may be the abandonment of economic strategies that sufficed for a century or more. Civic leaders across the country chase high-tech industry. Manufacturing cities seek positions in the transactional economy. Other communities try to devise new roles as international retail cities, travel destinations, amateur sports centers, or health care centers.

Debates about the future of American cities draw heavily on academic expertise in economics, planning, regional science, and related fields. Book catalogs in these applied fields are filled with city and regional case studies whose titles or subtitles proclaim their interest in "deindustrialization," "reindustrialization," "economic prospects," "structural change," and "prospects for change."3 However, few studies are available to allow comparison of current economic planning concerns with past experiences. As a contribution toward a historically informed discussion of decisionmaking in economic restructuring, I have begun to explore the case of Washington, D.C., a city that has never found it easy to achieve a "natural" economic role. It has experienced an ambiguous regional orientation, uncertain opportunities, and entrenched preconceptions about appropriate activities. In particular, the generation of Washington leaders following the upheavals of Civil War and Reconstruction faced a need for economic redirection with parallels to the deindustrializing factory towns of the 1970s and 1980s.

The focus of this examination is the evolving character of ideas on Washington's potentials as an economic entity. Washingtonians have engaged in an ongoing "conversation" or discussion about the possibilities of

2. Edward M. Bergman, ed., Local Economies in Transition: Policy Realities and Development Potentials (Durham: Duke University Press, IS $\rightarrow$ Roger S. Ahlbrandt, Jr. and Clyde Weaver, "Public-Private Institutions and Advanced Technology Development in Southwestern Pennsylvania," Journal of the American Planning Association 53 (Autumn 1987), 449-58; Dennis R. Judd and Randy L. Ready, "Entrepreneurial Cities and the New Politics of Economic Development," in George Peterson and Carol Lewis, eds., Reagan and the Cities (Washington, D.C.: Urban Institute Press, 1986), 209- $\rightarrow$ Dewey Bandy, "Local Development Planning in the 1980s," Journal of Planning Literature 2 (Spring 1987), 136-52.

3. Richard Child Hill, "Crisis in the Motor City: The Politics of Economic Redevelopment in Detroit," in Norman Fainstein and Susan Fainstein, eds., Restructuring the City (New York: Longman, Inc., 1986), 80-125; Harry W. Richardson and Joseph H. Turek, eds., Economic Prospects for the Northeast (Philadelphia: Temple University Press, 1985); Barry Checkoway and Carl Patton, eds., The Metropolitan Midwest: Policy Problems and Prospects for Change (Urbana: University of Illinois Press, 1985); Morton Schoolman and Alvin Magid, eds., Reindustrializing New York State: Strategies, Implications, Challenges (Albany: SUNY Press, 1986); David McKee and Richard Bennett, eds., Structural Change in an Urban Industrial Region: The Northeast Ohio Case (New York: Praeger, 1987). 
Table 1. GROWTH OF FEDERAL CIVILIAN EMPLOYMENT IN RELATION TO POPULATION

\begin{tabular}{lcc}
\hline & $\begin{array}{c}\text { Change in } \\
\text { Federal Jobs }\end{array}$ & $\begin{array}{c}\text { Change as Percent of } \\
\text { Beginning Population }\end{array}$ \\
\hline $1851-61$ & 666 & 1.3 percent \\
$1861-71$ & 4,023 & 5.4 \\
$1871-81$ & 6,902 & 5.2 \\
$1881-91$ & 7,710 & 4.3 \\
$1891-1901$ & 7,760 & 3.7 \\
$1901-1910$ & 10,867 & 3.9 \\
$1910-20$ & 55,199 & 16.7 \\
$1920-30$ & $-21,078$ & -4.8 \\
$1930-40$ & 66,738 & 13.7 \\
$1940-50$ & 83,542 & 9.2 \\
$1950-60$ & 16,561 & 1.1 \\
$1960-70$ & 87,496 & 4.4 \\
$1970-80$ & 18,631 & 0.7 \\
\hline
\end{tabular}

Base populations through 1930 are for the District of Columbia; for 1940 for the Washington Metropolitan District; for 1950-70 for the Washington metropolitan area. Through 1900, the beginning population is taken at the census year.

Sources: Historical Statistics of the United States and U. S. Office of Personnel Management, Federal Civilian Workforce Statistics: Annual Report by Geographical Areas (1980)

economic development. ${ }^{4}$ My interest lies in the articulation and evolution of public ideas, not in the separate questions of the implementation process or the equitable division of the benefits of growth. Ideas about economic development may have their final test as they affect the production and distribution of wealth, but they also have careers as intellectual constructs that express a social context of power and values.

Because of the continuing presence of the federal government as a guarantor against complete economic obsolescence, it might be argued that Washington's economic debate lacked the same do-or-die character of such debates in other cities. In fact, most economic strategy in established cities has to do with choices at the margin, whether they involve additions to a governmental or a manufacturing employment base. Participants in the Washington conversation were seeking ways to expand a profitable economy on the federal foundation. It is also worth noting that the level of interest in Washington rose between 1880 and 1914 and again during the 1950s and 1970s, all times of relative stability in Washington's federal employment following periods of more rapid expansion (see Table 1).

4. Use of the term "conversation" is borrowed by analogy from Thomas Bender's recent description of the protracted and fragmented discourse about the character of New York as an intellectual community in New York Intellect: A History of Intellectual Life in New York City, from 1750 to the Beginnings of Our Own Time (New York: Alfred A. Knopf, 1987). 
Exploration of Washington's experience with economic strategy-making can also help to amplify a relatively undeveloped topic in the historiography of urban economic growth and planning. Historians have a broadly based understanding of the importance of a business-based growth consensus and growth coalitions in shaping public decisions in American cities. Wide-ranging historical case studies supplement a substantial body of social science theory detailing the dynamics of the entrepreneurial city. ${ }^{5}$ An even more extensive literature describes the specific techniques of promotion and development that have been tried and tested by urban business and political leaders through nearly two centuries. ${ }^{6}$

Between acceptance of growth as a major civic goal and the choice of particular promotional techniques and programs, however, is an intermediate step of developing and articulating a growth strategy to guide government bodies, community organizations, and perhaps private entrepreneurs. The process of community entrepreneurship has required decisions on the orientation of hinterlands, on promising industries, and on the balance among basic sectors within the economy. Indeed, cities as arenas for decisions about economic development are analogous to more clearly delimited institutions such as business firms, government agencies, or nonprofit corporations, all of which analyze their changing environments as the basis for strategic decisions about future mixes of products and services. ${ }^{7}$

One reason for neglect of this middle step may be the relative stability of the American urban system since the middle 1800s. Once past the first decades of settlement and transportation development on successive frontiers, most cities have performed the same roles and functions over several generations, offering few cases of fundamental change to challenge

5. For theoretical statements see Oliver Williams, "A Typology for Comparative Local Government," Midwest Journal of Political Science 5 (May 1961), 150-64; Harvey Molotch, "The City as a Growth Machine," American Journal of Sociology 82 (September 1976), 30932; John Logan and Harvey Molotch, Urban Fortunes (Berkeley: University of California Press, 1987); Mark Gottdiener, The Social Production of Urban Space (Austin: University of Texas Press, 19l $\rightarrow$ Stephen L. Elkin, "Twentieth Century Urban Regimes," Journal of Urban Affairs 7 (Spring 1985), 11-28; Arnold Fleischmann and Joe R. Feagin, "The Politics of Growth-Oriented Urban Alliances," Urban Affairs Quarterly 23 (December 1987), 20732; John Mollenkopf, The Contested City (Princeton: Princeton University Press, 1983). For general historical statements, see Daniel Boorstin, The Americans: The National Experience (New York: Random House, 1965), 118; Blaine Brownell, The Urban Ethos in the South, 1920-1930 (Baton Rouge: Louisiana State University Press, 1975), xix, 125; Gunther Barth, Instant Cities (New York: Oxford University Press, 1976), 128-54.

6. Charles Glaab, "Historical Perspective on Urban Development Schemes," in Leo F. Schnore, ed., Social Science and the City (New York: Praeger, 1968), 197-219; Elizabeth Bloomfield, "Community, Ethos, and Local Initiative in Urban Economic Growth: A Review of a Theme in Canadian Urban History," Urban History Yearbook (1983), 53-72.

7. Arthur Cole, Business Enterprise in Its Social Setting (Cambridge: Harvard University Press, 1959), 108-9, 124-28, 161-64; Carl Abbott, Boosters and Businessmen: Popular Economic Thought and Urban Growth in the Antebellum Middle West (Westport, Conn.: Greenwood Press, 1981). The applicability of corporate strategic planning to public sector activities is the subject of a special issue of the Journal of the American Planning Association 53 (Winter 1987). 
historical explanation. ${ }^{8}$ As promising cases for analysis of urban strategymaking, however, it is possible to identify periods and regions in which sets of cities faced changes in their economic circumstances comparable to those of the current era. One example might be western resource cities in the era of agricultural and mining depression after World War I. ${ }^{9}$ Another might be the cities of the postbellum and postreconstruction South as they faced changed patterns of trade, markets, and leadership. ${ }^{10}$

\section{Washington and the New Century}

Washington, D.C., entered the last two decades of the nineteenth century in much the same circumstances as other urban centers of the New South. New. arrivals from Vermont, New York, and Ohio challenged native Washingtonians for local business leadership. ${ }^{11}$ The city's commercial ambitions were disrupted, its finances dominated by cities to the north, and the future of its potential hinterland uncertain. Indeed, little had gone according to plan during the preceding quarter century. During the 1850s, the limited impact of the Chesapeake and Ohio Canal and the isolation of Washington within the growing American railroad system had ended hopes to turn Washington into a diversified manufacturing and trading center on the model of Philadelphia. The Civil War brought flush

8. John Borchert's data show that most cities that emerged in the canal and railroad eras of urban development retained their importance in successive generations ("American Metropolitan Evolution," Geographical Review 57 [July 1967], 301-32).

9. Roger Lotchin, "The City and the Sword: San Francisco and the Rise of the Metropolitan Military Complex, 1919-41," Journal of American History 65 (March 1979), 9961020; Roger Lotchin, "City and the Sword in Metropolitan California, 1919-1941," Urbanism Past and Present 7 (1982), 1-16; David R. Johnson, "The Failed Experiment: Military Aviation and Urban Development in San Antonio, 1910-1940," in Roger Lotchin, ed., The Martial Metropolis (New York: Praeger, 1984), 89-108; Eugene Moehring, Resort City in the Sunbelt: Las Vegas, 1930-1970 (Reno: University of Nevada Press, 1989).

10. Dana White and Timothy Crimmins, "How Atlanta Grew: Cool Heads, Hot Air, and Hard Work," in Andrew M. Hamer, ed., Urban Atlanta: Redefining the Role of the City (Atlanta: Georgia State University, 1980), 25-44; Don Doyle, Nashville in the New South: 1880-1930 (Knoxville: University of Tennessee Press, 1985), 212-32, and Nashville since the 1920s (Knoxville: University of Tennessee Press, 1985), 143-78.

11. Washington's dominant commercial organization for the last century has been the Washington Board of Trade. When it was founded in 1889, its first directors included three men born in Washington, five born in the South, three born abroad, and eleven born in the North. The median arrival date in Washington for the northerners was approximately 1870 . Biographical data from the following sources: John P. Coffin, Washington: Historical Sketches of the Capital City of Our Country (Washington, D.C., 1887); Leading Merchants and Manufacturers of the City of Washington: A Resume of Trade, Enterprise, and Development (New York: International Publishing Co., 1887); Eminent and Representative Men of Virginia and the District of Columbia of the Nineteenth Century (Madison: Brant and Fuller, 1893); A. K. Parris and W. A. Means, eds., Investor's Handbook of Washington Securities (Washington, 1900); Allan B. Slauson, ed., History of the City of Washington: Its Men and Institutions (Washington, D.C., The Washington Post, 1903); District of Columbia: Concise Biographies of Its Prominent and Representative Contemporary Citizens, and Valuable Statistical Data, 1908-09 (Washington, D.C., The Potomac Press, 1908). 
times to local retail and service businesses, but it also occasioned a flight of capital and interrupted regional trade. ${ }^{12}$ Development efforts in the immediate postbellum years failed to change Washington's status as “a mere appendage of Baltimore." 13 The onset of depression in the 1870s and the rapid rise and fall of Alexander Shepherd as the Haussmann of Washington left the city undirected and ill-at-ease.

By the last decades of the century, in short, it was clear that the city's historic ambitions were illusory. Save for the presence of the federal government, the city might have faded into a backwater like scores of other river towns bypassed in the railroad era. In fact, the number of federal jobs in Washington increased six-fold from 1860 to 1880 , to be followed by slower expansion over the next generation. The federal establishment after 1880 thus gave Washington a base of economic support but limited direct stimulus to further growth and diversification, leaving local businessmen eager to define and develop their own economic strategy to capitalize on the federal foundation.

Gradually in the 1880s and with increasing clarity toward the turn of the century, Washington businessmen responded to this uncertain present by formulating two distinct versions of their city's economic future. One argument found Washington's future as the manufacturing, distributing, and banking center for the Virginias, Carolinas, and points south. In a phrase, advocates of this view envisioned a New York of the South. Other residents described Washington's potential as a unique national city that could lead the United States in education and the arts and house its national institutions. The city, they hoped, could be the Vienna or Paris of America.

The forums for economic discussion were the nineteenth-century standards-newspapers such as the Washington Star and Washington Post and local commercial organizations. Prominent business and civic leaders established the Washington Board of Trade in 1889. The first directors included the publishers of the Star and Post, leading retailers, manufacturers, bankers, and attorneys. Washingtonians soon accepted that the Board of Trade spoke for the local market businessmen and investors in areas ranging from economic development to government and public services. The Chamber of Commerce, appearing in 1908, defined its goal more narrowly as a "Greater Commercial Washington." Its membership overlapped the Board of Trade but with heavier represen-

12. Constance M. Green, Washington: Village and Capital, 1800-1878 (Princeton: Princeton University Press, 1962), 113-18, 157, 192-94, 263, 293; Frederick Gutheim, The Potomac (New York: Grosset and Dunlap, 1968), 268, 275.

13. Elizabeth Miller, "The Washington Business Community in the Nineteenth Century: Dreams and Disappointments," manuscript in library of Columbia Historical Society, Washington; Harvey W. Crew, ed., Centennial History of Washington, D.C. (Dayton, Ohio: United Brethren Publishing House, 1892), 413; Report of the Joint Committee on Manufactures of the Legislative Assembly of the District of Columbia (Washington, D.C., 1872), 22. 
tation of smaller retailers and wholesalers. As in other nineteenth-century cities, professional publicists and journalists completed the set of active discussants. ${ }^{14}$

In many respects, the Washington Board of Trade functioned as a shadow government into the 1950s. The federally appointed commissioners who governed Washington after 1878 took care of basic urban services, but offered District of Columbia residents little opportunity for direct participation in local affairs. In response, the Board of Trade assumed a quasi-governmental role, claiming to represent all sectors and interests of the city in relation to economic development, planning, and public service needs. Its claim is as valid as that of many formally representative business-reform governments of the 1910s and 1920s or the neoprogressive city administrations that worked the will of business coalitions in the decades after World War II. There is no reason to think that strategic thinking proceeded any differently in Washington than in Dallas, Phoenix, Omaha, or other cities where nonbusiness interests were systematically disregarded. ${ }^{15}$

Washington as the business center for the New South was an idea that fell easily into the practiced rhetoric of American boosterism. Washingtonians phrased the city's southern strategy in the familiar language of inevitability. It had "great advantages" in the South, it was "destined" to utilize southern resources, it was a "natural," "proper," and "logical" center for southern business. ${ }^{16}$ In one view of natural advantages, Washington was the "Gateway to the South from the North Atlantic States" for travelers and merchandise. Southerners seeking the summer resorts of the North and northerners looking to winter in the South would find Washington a natural stopover. To capture business travelers, Washington wholesalers needed only to expand their stocks of goods and intercept southern storekeepers before they reached Baltimore or New York. In a complementary emphasis, Washington was presumably the most convenient assembly and processing point for the raw materials of the Southcoal, cotton, and lumber on every list, tobacco, iron, sulphur, and phos-

14. Washington Board of Trade, Twenty-Seventh Annual Report (1917-18), 12-13; Washington Chamber of Commerce, First Annual Report (January 14, 1908), 3; Constance M. Green, Washington: Capital City, 1879-1950 (Princeton: Princeton University Press, 1963), 30-31; The Book of Washington, Sponsored by the Washington Board of Trade (Washington, D.C., 1930), 3, 7, 250.

15. Frederick Gutheim, Worthy of the Nation: The History of Planning for the National Capital (Washington, D.C.: Smithsonian Institution Press, 1977), 166-67; Harold A. Stone, Don K. Price, and Kathryn H. Stone, City Manager Government in Nine Cities (Chicago: Public Administration Service, 1940); Carl Abbott, The New Urban America: Growth and Politics in Sunbelt Cities, revised ed. (Chapel Hill: University of North Carolina Press, 1987).

16. Washington Board of Trade, Fifteenth Annual Report (November 1905), 50, Nineteenth Annual Report (November 1909), 59; The Washington Enterprise 1 (August 8, 1906); Washington Post, "Prosperous Washington," June 11, 1912, 53; Washington Chamber of Commerce, First Annual Report (January 14, 1908), 5; The Southern Commercial 1 (October 15,1906$), 5$. 
phates on one or another. Northern capital and local entrepreneurship could combine to turn the region's natural products into manufactured goods and ship them back to southern customers. ${ }^{17}$

Growing interest in southern markets was tied to the improvement of Washington's southward rail connections. J. P. Morgan built the Southern Railway system in the mid-1890s on the foundation of the Richmond and Danville Railroad, locating the executive offices in New York but the operating office in Washington. The Southern operated a main line through the Piedmont and secondary lines to south Atlantic ports and the southern Ohio Valley. The new Atlantic Coast Line and Seaboard Air Line, assembled from smaller companies by Richmond and Baltimore capitalists, linked Chesapeake Bay cities to the Tidewater and Florida. ${ }^{18}$

The Southern Railway showed a special interest in promoting its headquarters city and northern terminus and in attracting settlers and investors into the South. Its managers claimed to be "not merely a carrier of the people and products of the South, but also a helpful factor in Southern development." Its Land and Industrial Department published the monthly Southern Field from 1895 to 1905 . It boosted southern progress and opportunities in resource production and manufacturing, Washington's economy, and northern Virginia as a locale for country estates and winter homes. "As Washington is the gateway to the Southland," said an 1898 pamphlet, "there is sentimental as well as business justification for locating here the headquarters of this, the greatest and most comprehensive transportation company in the South." 19

Interest in a southern strategy peaked during the national boom of 1905 to 1912. Washingtonians argued that their own city would rise in tandem

17. Washington Board of Trade, Tenth Annual Report (November 1900), 57-58; Eleventh Annual Report (1901), 53; Twenty-Fifth Annual Report (1915-16), 7-8; Louis P. Shoemaker, Manufacturing in the District of Columbia and Its Influence on the United States, Copied from the Evening Star and Reprinted by the Business Men's Association (Washington: Judd and Detweiler, 1905); George H. Gall, Washington: Industrial, Commercial and Civic Features (Washington, D.C.: Washington Chamber of Commerce, 1908); Washington Condensed: Five Thousand Facts for Ready Reference (Washington, D.C.: Bert S. Elliott, 1909), 10; Jobbers and Shippers Trade Journal August 8 and September 15, 1906. Trade and manufacturing would presumably support an expanded financial role. According to $\mathrm{J}$. Selwyn Tait, President of the Washington and Southern Bank, the city "should rapidly become to the South the banking center which New York is now to the country at large" (quoted in George Gall, The New Washington and the South [Washington, D.C.: Southern Commercial Congress, 1915], 43).

18. John F. Stover, The Railroads of the South, 1865-1900: A Study in Finance and Control (Chapel Hill: University of North Carolina Press, 1955), 233-53, 263-73; Burke Davis, The Southern Railway: Road of the Innovators (Chapel Hill: University of North Carolina Press, 1985), 38, 66; Howard D. Dozier, A History of the Atlantic Coast Line Railroad (Boston: Houghton Mifflin Co., 1920).

19. Southern Railway Company, Seventeenth Annual Report (1910-11), 8; Fairfax Harrison, The South and the Southern Railway: The Statement of a Record and of an Ambition: An Address before the Virginia Bankers Association (Washington, 1916), 15; The Southern Field 9 (May 1904), 6, (Sept. 1904), 8; Frank Presbrey, The Southland (Washington, D.C.: Southern Railway Co., 1898). 
with the "progress of the rejuvenated South." 20 Newspapers and booster literature cited Washington wholesale, business service, and construction firms whose trade extended as far as Tennessee and Alabama. The Washington Star chartered a "trade-getting train" that hauled a contingent of businessmen and exhibit cars to Lynchburg, Roanoke, Raleigh, and their neighbors. The result, claimed one booster in 1906, was to call into play "a new public opinion which has resulted in the cry for 'Greater Washington' that has not only thrilled the District of Columbia, but the whole South."21

The alternative vision of Washington as a second Paris lacked the supporting tradition of urban imperialism. Washington's function as the federal city-the presumably neutral seat of government-was set by constitution, law, and custom. The later nineteenth century, however, brought increasing interest in building on the federal role to become a true $n a$ tional city -a multi-faceted capital that attracted national institutions, private decision centers, public attention, and patriotic pride. Alexander Anderson's 1897 volume on Greater Washington: The Nation's City Viewed from a Material Standpoint, for example, argued that Washington was destined to be a "paradise for authors" and the "great University City of America" because of access to the Library of Congress and the federal science establishment. It was already headquarters for a number of national organizations interested in "the promotion of great and important public movements" and a focal point for national conventions and travel. In Anderson's view, it could aspire to be the Rome of America in the arts, the Berlin of America in educational advantages, and the Paris of America as a city of beauty and pleasure. ${ }^{22}$

Washington boosters found it easy to assert that their city was special. Thomas Presbrey, writing for the Southern Railway, found its only peers in the major capitals of Europe. Newspaper editor Theodore Noyes, in a presidential report to the Board of Trade, claimed that Washington could expect to take its growth automatically from national expansion, for "the greater the current of national life, the larger and stronger the heart." Real estate developer Arthur Randle agreed that national capitals always grew into their country's greatest cities. ${ }^{23}$

It was harder to figure out the specifics of a national strategy. Although one writer claimed that Washington's equal convenience to North and

20. Washington Enterprise, September 8, 1906; The Southern Commercial 1 (October 1, 1906); Washington Board of Trade, Fifteenth Annual Report (November 1905), 50.

21. Washington Post, "Prosperous Washington," 55.

22. Alexander Anderson, Greater Washington: The Nation's City Viewed from a Material Standpoint (Washington, D.C.: Hartman and Chadwick, Printers, 1897).

23. Presbrey, Southland; Theodore W. Noyes, in Washington Board of Trade, Eighth Annual Report (November 1898), 27-28; Arthur E. Randle, "The Future of Washington [1899]," in Ulmo S. Randle, Reminiscences (Washington, D.C.: Judd and Detweiler, 1924). These assertions of Washington's national role followed closely on the publication of James Bryce's The American Commonwealth (1893), which argued that the United States had no true capital and dismissed Washington in two paragraphs. 
South would make it an educational center, geographical reasoning offered limited insight into a role that required the accretion of private activities that might benefit from proximity to the federal government. ${ }^{24}$ Some of these activities depended on external "investors" such as the bishops who located the Catholic University of America in 1889 or the Methodists who founded American University in 1898. The expansion of offices of various associations and organizations likewise depended on external decisions.

National convention business offered one of the few specific areas for local promotion. As early as 1903, the Board of Trade reported that the annual number of major gatherings had doubled in a decade. After 1908, the new Chamber of Commerce defined conventions as "great commercial resources" and took the lead in convention recruitment, in cooperation with the Board of Trade and the Retail Merchants Association. The image of Washington as a second Paris was a direct promotional tool for the convention trade. ${ }^{25}$ Like the southern strategy, attention to conventions and to private tourism (as indicated by the volume of Washington tourbooks and illustrated guides published in the early 1900s) was tied to the completion of the American railroad system. Improving service and falling passenger fares were greatly facilitating middle-class travel, opening a new age of planned excursions, national expositions, and civic festivals that catered to school teachers, families, and small businessmen. ${ }^{26}$ Washington rolled out its southern hospitality for conventioneers, served as a jumping off point for southern resorts, and promoted the Jamestown Exposition in 1907. ${ }^{27}$

The major countercurrent to the early-twentieth-century development strategies was a half-spoken concern about spoiling the amenities of Washington as a ceremonial and residential center with dirty, ugly factories. The Board of Trade periodically argued that the proper choice of manufacturing categories and sites could ensure industrial growth without detrimental effects. ${ }^{28}$ One presumable target of these reassurances was Congressmen who wanted to keep the city's white palaces free from soot and its streets free from industrial workers. Another target was the military retirees and the "men of wealth or political prominence" who had estab-

24. Washington Post, "Prosperous Washington," 21.

25. Washington Board of Trade, Thirteenth Annual Report (1903), 22, Twenty-Second Annual Report (November 1912), 8; Anderson, Greater Washington, 62; Washington Chamber of Commerce, Annual Report (January 14, 1919), 5.

26. Earl Pomeroy, In Search of the Golden West: The Tourist in Western America (New York: Alfred A. Knopf, 1957); John Jakle, The Tourist: Travel in Twentieth Century North America (Lincoln: University of Nebraska Press, 1985). There were nine major national/ international expositions in the United States from 1897 through 1915.

27. Southern Commercial 1 (December 15, 1906); W. Y. Barnet, "Washington Entertains Bankers," The Banking and Mercantile World 7 (November-December 1905), 206.

28. Washington Board of Trade, Eighth Annual Report (1898), 46-47, Tenth Annual Report (1900), 58-59; Green, Washington: Capital City, 174. 
lished Washington homes without any interest in the city's economic development. ${ }^{29}$

By and large, Washington's federal supervisors ignored the concerns of local economic growth. From the time of the McMillan Commission and plan in the early years of the century, Congress centered its attention on the creation and embellishment of what Frederick Gutheim has called the "public city" of federal offices and national institutions. Physical development ideas and plans evolved through the work of the Commission on Fine Arts (1910), the National Capital Park Commission (1924), the National Capital Park and Planning Commission (1926), and the National Capital Regional Planning Commission (1952). In turn, a limited set of federal decisionmakers responded to a focused planning agenda with the investments that shaped Washington's parks, monuments, and public spaces. ${ }^{30}$

Washington's black community also sat out the local economic debate. The city's substantial black elite was essentially noncommercial in employment and interests. Washington listings in national black Who's Who volumes for 1915, 1928, and 1950 confirm the general impression of a cultured community of university faculty, high school teachers, government workers, lawyers, and clergy. Three-quarters of the persons listed each year worked in education, the arts, or the learned professions. The other quarter consisted of an increasing proportion of civil servants and a decreasing proportion of small businessmen. ${ }^{31}$ The segregation of the Washington Board of Trade early in the twentieth century excluded several blacks of significant economic standing, such as hotel owner and building contractor James T. Wormley, from direct participation in the economic dialogue. The District of Columbia Chamber of Commerce, which emerged as the major black business organization, represented small business operators such as insurance agents, undertakers, dry cleaners, beauticians, realtors, and others with purely local market interests. ${ }^{32}$

By implication, the black elite saw its future within the "Paris" strategy of a national cultural center. The centerpiece was Howard University,

29. Shoemaker, Manufacturing in the District of Columbia; Carroll D. Wright, "The Economic Development of Washington," Proceedings of the Washington Academy of Sciences 1 (December 1899), 180-82; Julian Street, "Wartime Washington," Saturday Evening Post 190 (March 2, 1918), 3.

30. John Reps, Monumental Washington: The Planning and Development of the Capital Center (Princeton: Princeton University Press, 1967); Frederick Gutheim, The Federal City: Plans and Realities (Washington, D.C.: Smithsonian Institution Press, 1976); Gutheim, Worthy of the Nation.

31. Frank Lincoln Mather, ed., Who's Who of the Colored Race: General Biographical Dictionary of Men and Women of African Descent (Chicago, 1915); Thomas Yesner, Who's Who in Colored America: 1928-29 (Brooklyn: Who's Who in Colored America Corporation, 1928); James G. Fleming and Christian E. Burckel, Who's Who in Colored America, 1950 (Yonkers-on-Hudson, NY: Christian Burckel and Associates, 1950).

32. Constance M. Green, The Secret City: A History of Race Relations in the Nation's Capital (Princeton: Princeton University Press, 1967), 133, 162-63; Haynes Johnson, Dusk at the Mountain (Garden City, N.Y.: Doubleday, 1963), 217-18. 
conceived as a "national Negro university" and proudly promoted as "the Capstone of Negro Education." The presence of the Howard faculty made Washington a significant center of literary and artistic work into the mid1920s. Washington's national role also attracted the headquarters of scholarly organizations such as the American Negro Academy (1897) and the Association for the Study of Negro Life and History (1915). Within the obvious priorities of Washington's black leadership, however, the city's national role was taken as a valuable precondition to institutional development rather than as a goal in itself. ${ }^{33}$

\section{Strategic Images in Contemporary Washington}

Washington's turn-of-the-century strategies coexisted for the next forty years as assumptions that needed only occasional elaboration. The Washington Chamber of Commerce (until merger into the Board of Trade 1934) and the Board of Trade itself continued to push the vision of a national city with the promotion of conventions, tourism, and air travel. Interest in a federally financed National Cultural Center or National Theater (growing gradually from the 1930s and culminating in the Kennedy Center) marked one of the few instances of a direct federal role in local economic development. ${ }^{34}$ The doctrine of southern resources was also restated in industrial surveys and economic planning documents. Washington as the portal to the South Atlantic states remained a standard theme into the $1950 \mathrm{~s}$, when the Board of Trade's economic research department mapped a hinterland that extended only 100 miles to the north but 400 miles southward. ${ }^{35}$ Atlanta now appeared more often than Richmond as Washington's chief competitor and comparator, but the southward tilt remained. ${ }^{36}$

33. Ronald M. Johnson, "Those Who Stayed: Washington Black Writers of the 1920s," Records of the Columbia Historical Society 50 (1980), 484-99; Letitia W. Brown and Elsie M. Lewis, Washington in the New Era, 1870-1970 (Washington, D.C.: Government Printing Office, 1972), 23-28; Rayford W. Logan, Howard University: The First Hundred Years, 1867-1967 (New York: New York University Press, 1969).

34. Industrial Survey of the Washington Metropolitan Area (Washington: Joint Industrial Council, 1928); Washington Chamber of Commerce, Greater Washington [monthly magazine], 1920-33; Book of Washington; Washington Board of Trade, President's Annual Report for 1936-37, for 1950-51, in Board of Trade Papers, George Washington University Library; Roger Meersman, "The John F. Kennedy Center for the Performing Arts: From Dream to Reality," Records of the Columbia Historical Society 50 (1980), 535-88.

35. Washington Board of Trade, It's a Capital Idea (First-Fifth editions, 1955-59); Headquarters USA . . . the Story of Profit and Prestige on the Potomac: An Area Survey by Industrial Development and Manufacturers Record, reprinted from Industrial Development, February 1959, 18-39.

36. For early and later citations of comparators, see Washington Board of Trade, Twelfth Annual Report (1902), 10; The Southern Commercial 1 (October 1, 1906), 9, 16; William B. Wrench, Executive Director, Fairfax County Economic and Industrial Development Committee, in Washington Metropolitan Area Economic Development: Hearings before the Joint Committee on Washington Metropolitan Problems, July 8-10, 1958, 85th Cong., 2d sess., 64; "Marketing Concept for the Baltimore/Washington Common Market," June 1976, in Board of Trade Papers, George Washington University. 
It is likely that Washingtonians gave less attention than previously to local economic development issues because so many other changes were in process. The Depression, New Deal, and war transformed Washington after 1930. Federal civilian employment jumped from 62,000 in 1930 to 230,000 in 1950 . Metropolitan population in the same years grew from 621,000 to $1,464,000 .{ }^{37}$ Local tradition remembers a painful end to southern gentility in the face of hordes of new bureaucrats and professionals from Yankee cities and Yankee universities. Mississippian John Stennis, for one, recalled the postwar erosion of "southern attitudes in the social realm-neighborliness, friendliness, conviviality." Business proprietors began in the 1940s to incorporate "Atlantic," "mid-states" and other neutral terms in their company name in preference to "southern" or "dixie." 38

Simultaneous with these changes in metropolitan Washington was a change in the community of discourse on economic strategy. To the businessmen and journalists who dominated debate from the 1880s to the 1940 s were added academically trained development specialists acting as staff or consultants to government agencies and business organizations. Discussion of natural advantages using the spatially based rhetoric of the nineteenth century began to give place to the analysis of industrial advantages using the general categories of modern economics. Instead of sweeping perorations on the possibilities of commercial empire, the new professional reports offered technically phrased employment projections and forecasts presented through a wealth of catchy bar graphs, trend charts, and other visual substitutes for the apt phrase. ${ }^{39}$

One result of the changing approach and rhetoric was to erode the geographical orientation of the "southern" strategy. A new professional development staff helped the Board of Trade redefine its goals as the attraction of national organizations and business headquarters, wholesaling, and regional business offices. The first point recycled the national strategy. The two latter points reworked the historic southern strategy without regional reference. Widely used consulting reports by the Council for Economic and Industrial Research and by Hamer and Associates further changed the terms of discussion by treating local and regional demand for manufacturing and wholesaling without direct reference to the rising South as the targeted market. ${ }^{40}$

37. Postwar Planning Committee, Washington Board of Trade, People, Jobs, Homes: Metropolitan Washington (1946); Metropolitan Washington Council of Governments, An Economic Profile of the Washington Region (Washington, D.C., 1980), 52.

38. Quoted in Howard Means, "The Northernization of Washington," Washingtonian 13 (August 1978), 82. Also see Gore Vidal, Washington, D.C. (Boston: Little Brown, 1967), 251 .

39. For an example of the new style, see the Policies Plan for the Year 2000: The Nation's Capital (Washington, D.C., National Capital Planning Commission and National Capital Regional Planning Council, 1961).

40. Metropolitan Washington Board of Trade, "Summary of Activities, 1954-1970," in Board of Trade Papers, George Washington University; Council for Economic and Industry Research, Inc., Economic Base Survey for the General Development Plan, National Capital 
Success as a national center since the 1960s has also fed a new and grander vision of Washington as an international center. Explosive metropolitan growth, especially in the 1960s and 1980s, has been heavily based on "national capital functions." Washington has become a center for national institutions and business activity, including federal scientific and cultural institutions, lobbyists, and trade organizations ("AAA" in the Washington parlance, meaning attorneys, associations, and accountants). A handful of corporate headquarters have begun to relocate from northeastern industrial cities. ${ }^{41}$ On the basis of this increasingly prominent national role, Washington business leaders such as developer Oliver Carr and Board of Trade executive John Tydings began to argue in the 1970s that Washington was growing into an international business city. By the 1980s, civic organizations have found it reasonable to assert that Washington was an international political and financial coordinating center or a "world center of research and information." The Washington Post supported the new world-city image with stories on the city's cosmopolitan character-foreign real estate investment, foreign residents, and even the number of Washingtonians holding passports (twice the proportion held in Detroit or Dallas). ${ }^{42}$

The same factors that worked to make Washington a national business and information center presumably worked as well on the international scale. The Board of Trade's 1987 promotional brochure argued that Washington is the place to be for companies engaged in world markets. It houses key international financial institutions in the World Bank, International Monetary Fund, and Import-Export Bank and offers crucial access to information. "For American firms," argue the boosters, "Greater Washington offers a community of worldwide investment and trade organizations which create an entree to the far corners of the earth. For interna-

Region (1956); Hamer and Company Associates, "Economic Development in the Washington Area," staff study for the Joint Congressional Committee on Washington Area Problems (1958).

41. See, for example, Gail Garfield Schwartz, Technology Oriented Firms in the Washington Area (Washington, D.C., Greater Washington Research Center, 1984); Edward J. Malecki, "Science and Technology in the American Metropolitan System," in Stanley Brunn and James $\mathrm{O}$. Wheeler, eds., The American Metropolitan System: Present and Future (New York: John Wiley and Sons, 1980); Washington Star, November 26, 1974; "Trade Groups Flock to Washington," Washington Post, Feb. 14, 1987; “Area Has 50 of Nation's 1000 Most Valuable Companies," Washington Post, April 20, 1987.

42. Metropolitan Washington Council of Governments, Economic Profile, 1-4; Oliver T. Carr, transcript of remarks at inauguration of Mayor Marion Berry, Jan. 3, 1978, and John R. Tydings, statement to Metropolitan Washington Savings and Loan League, May 27, 1978, both in Board of Trade Papers, George Washington University; Atlee Shidler, "Local Community and National Government," in Shidler, ed., Greater Washington in 1980 (Washington: Greater Washington Research Center, 1980), 13-14; Government of the District of Columbia, Comprehensive Plan for the National Capital (Washington, D.C., 1983), 81; Washington Post, Retail Memo and Sales Planner 22 (February 1984); "Washington: The New International City," Washington Post, February 3, 1980. 
tional firms, Washington offers the U. S. base of operations close to the government regulatory agencies which oversee import/export trade."43 The result is now the denial that Washington has any North American rivals except New York and possibly Los Angeles. "The most important city in the world" is now a common phrase around town. ${ }^{44}$

\section{Conclusion}

Because Washington is a special case among American cities, we need to take care in looking for generalizations to help the present generation of economic planners and urban strategists understand more fully the character of their task. As a city without the normal institutions of local selfgovernment until 1974, Washington may have exaggerated the importance of private institutions in the process of strategic analysis. In other cities as well, however, the private sector has often taken the lead with local government following ideas generated within the business elite. Washington's efforts to define appropriate incremental development on the foundation of government employment are substantially comparable to similar efforts in cities with previous growth based on manufacturing or regional services.

In this context, the experience of Washington reminds current participants in discussions of economic strategies and restructuring about the importance of continuity and persistence. Setting a new strategy is a gradual process in which ideas slowly coalesce around a compelling set of images and ideas. It took nearly a generation for the "southern" and "national city" strategies to develop into accepted visions of the city's future. The idea of Washington as a multi-purpose international center emerged over a quarter century between 1955 and 1980 .

The corollary of slow incubation has been long life. Once accepted as realistic and appropriate, development strategies were embedded deeply in local understanding. The southern strategy lasted for more than sixty years in public discourse, and the city's retail and service markets still tilt south. The idea of a national city also remains very much a part of Washington's economic planning. There is no reason to think that the vision of Washington as "the most important city in the world" will have any shorter life.

Much of this inertia derives from the power of compelling self-images.

43. Washington Board of Trade News 41 (December 1986), 10-11A; Washington Board of Trade, A Capital Link (Washington, D.C., 1987), 6.

44. Haynes Johnson, "The Capital of Success," The Washington Post Magazine, Feb. 2, 1986, 44. Interviews by author with Jack Limpert (Washingtonian magazine), April 9, 1987, William Regardie (Regardie's magazine), March 13, 1987, Joel Garreau (Washington Post), March 25, 1987. 
Well-accepted strategies link the future of a city to the broader realization of regional or national possibilities. It's telling that it is the idea of an international city that has excited Washingtonians during the 1980s rather than some of the alternatives such as "information center" or "research and development center" that are phrased in more technical and perhaps more precise terms. "International city" is an idea that the interested public can visualize in the same way that earlier generations could picture roles as a second New York or Paris.

Economic redefinitions in Washington have not been quick fixes for immediate crises. Structural change occurs over decades rather than years. For a recent example, the New England miracle of the 1980s is based on a generation of growth in the regional electronics industry and two generations of disinvestment, outmigration, obsolescing of labor skills, and loss of individual and corporate capital. Change in Washington has operated in a similar time frame. New strategies responded to long-run changes in the city and its environment. Both the 1890s and the 1970s, for example, brought major improvements in external transportation-better rail connections to the South and improvements in the national rail passenger system in the first case, increases in national and international air travel in the second. Strategic redefinition has also followed permanent increases in local federal employment. The ideas of 1890-1920 reflected basic changes in the character of Washington dating from the 1860s and 1870s. New ideas in the 1960s and 1970s followed another era of fundamental change between 1930 and 1950.

The experience in Washington and elsewhere suggests that privately based organizations may be particularly well positioned to foster the slow emergence of economic consensus. ${ }^{45}$ The repetitive formulation of economic strategies has limited appeal for elected officials who need visible accomplishments every two or four years. Political efforts at economic goal-setting, usually under the rubric of long-range planning, often land on the top shelf when one mayor or governor replaces another. Metropolitan newspapers, in contrast, have historically and currently assumed responsibility for proposing, analyzing, and promoting views of feasible economic futures. The Washington Star early in this century and the Washington Post in recent decades are good examples. Business organizations such as the Washington Board of Trade have the same sort of staying power. To the extent that their interests extend to conceptual planning as

45. There are parallels in the role of private organizations in the evolution of comprehensive city and regional land use and facility planning. An obvious example is the work of the Commercial Club of Chicago, the Chicago City Club, and the Chicago Regional Planning Association between 1905 and 1940. Other examples are the Pittsburgh Regional Planning Association or the Regional Plan Association of New York, which has supported systematic regional development planning since the 1920s. Examples of privately based organizations that have engaged in comprehensive economic development planning and implementation over protracted periods might include the Allegheny Conference on Community Development and the San Francisco Bay Area Council. 
well as to specific tasks of lobbying and promotion, they can contribute significantly to working new ideas into coherent wholes. ${ }^{46}$

46. Local government may complement and enrich the economic planning process in its potential openness to issues of equity. Whether in the $1880 \mathrm{~s}$ or $1980 \mathrm{~s}$, the local market businessmen and real estate holders who have dominated the definition of development strategies in Washington have found it natural to assume a "rising tide" theory in which everyone gains by increases in the overall level of economic activity. Since the advent of home rule in 1974, however, the Government of the District of Columbia has introduced what can be characterized as a "community development" agenda into economic planning. The city's efforts have centered on capturing a high share of metropolitan job growth and investment, with expected impacts on minority businesses, unemployment levels, and tax revenues. This approach assumes an aggregate level of economic activity in the metropolitan area and deals with the distribution of that activity by race and place. The economic development components of documents such as the Comprehensive Plan for the Nation's Capital, pp. 2, 24-5, 75-80, and Downtown DC: Recommendations for the Downtown Plan (1982), pp. 105-8, largely take the growth of the national and international city as a given for their discussions of such issues as neighborhood business revitalization, convention center job spinoffs, and the facilitation of downtown real estate projects. 